\title{
Kirjallisuutta
}

\section{Näkökulma aikuisen oppimiseen}

Kimmo Hypén, Esko Keskinen, Riitta Kinnunen, Pekka Niemi \& Marja Vauras: Aikuisen oppimisen psykologiset perusteet. Helsinki: Yleisradio/-opetusohjelmat, 1986.

Aikuiskasvatuksen avoimen korkeakouluopintojen toisen radiojakson oppikirjaksi tarkoitettu 'Aikuisen oppimisen psykologiset perusteet' edustaa kognitiivista oppimisnäkemystä. Oppiminen nähdään lähinnä asioiden mieleenpainamisena, jossa välineinä ovat erilaiset tiedolliset rakenteet (skeemat, sisäiset mallit) ja erilaiset oppimisen strategiat. Oppiminen puolestaan näkyy siinä, miten hyvin nämä asiat pysyvät mielessä ja miten hyvin ne on sieltä otettavissa käyttöön.

Kirjoittajat, Turun yliopiston psykologian laitoksen tutkijat, tarkastelevat edellä kuvattua oppimisnäkemystä kuudesta eri näkökulmasta: tiedonkäsittelyn, tietojen oppimisen, taitojen oppimisen, sosiaalisen vuorovaikutuksen, persoonallisen kehityksen ja opettamisen. Urakka on jakautunut siten, että Pekka Niemi tarkastelee aikuista ihmistä tiedonkäsittelijänä, Marja Vauras ja Riitta Kinnunen hahmottelevat tietojen oppimista sekä sosiaalisen vuorovaikutuksen merkitystä opetustilanteessa, Esko Keskinen keskittyy taitojen oppimiseen ja Kimmo Hypén kehitykselliseen näkökulmaan. Kirjan viimeinen luku, oppiminen ja opettaminen, ei esiinny sisällysluettelossa, eikä sitä myöskään kukaan tunnusta kirjoittaneensa.

Ensimmäisessä luvussa Pekka Niemi esittää aikuisen sisäisen apparaatin keskeiset tiedonkäsittelyä ohjaavat mekanismit, sekä niille asetetut rajoitukset. Lävitse käydään erilaiset muistit, skeemat, strategiat ja metakognitiot (= oman oppimisen kriittinen arviointi); rajoitukset hän jakaa yleisiin (esim. ennakkoluulot) ja henkilökohtaisiin (esim. arvot). Lopuksi oppiminen liitetään osaksi ihmisen maailmankuvaa ja minäkuvaa, kokonaispersoonallisuutta.

Tietojen oppimisessa on keskeistä Marja Vauraan ja Riitta Kinnusen mukaan ymmärtäminen, vuorovaikutus, tavoitteisuus ja strateginen toiminta. Aikuisopiskeluun liitetään ymmärtävä oppiminen, jossa päämääränä on käsitteellisten välineiden hankkiminen työssä, harrastuksessa, arkipäivässä ja yleensä elämässä kohdattavien ongelmien ratkaisemiseksi.

Taitojen oppimisessa siirrytään käsitteellisten välineiden kanssa todelliseen toimintaympäristöön, jossa taidot esiintyvät hierarkisesti järjestäytyneinä ja sisäisten mallien jäsentäminä kokonaisuuksina. Puhuttaessa taitavasta suorituksesta Esko Keskinen tuo esille palautteen, ennakointien, pelkistyneiden ulkoisten vihjeiden ja olosuhteiden merkityksen suoritustasoon vaikuttavina tekijöinä. Hän myös hahmottaa alustavasti, miten nämä tekijät voitaisiin huomioida taitojen opettamisessa.

Oppiminen ei tapahdu tyhjiössä, vaan siihen liittyy aina jonkinlainen sosiaalinen konteksti. Riitta Kinnunen ja Marja Vauras tarkastelevat opetustapahtumaa tällaisena kontekstina ja tekevät eron tehtäväkeskeisen ja yksilökeskeisen viestinnän välille tehokkaaseen oppimiseen johtavan vuorovaikutuksen edellytyksinä.

Kimmo Hypénin kehityksellinen näkökulma pitää si- sällään tarpeista ja motiiveista heräävän toiminnan säätelyjärjestelmän, jota hän pitää persoonallisuuden kuvauksena. Aikuisen elämäntilanne esitetään viiden elämänstrategian kautta. Lopuksi hän hahmottaa opettajien ja opiskelijoiden käsityksiä oppimisesta, mielekästä oppimista sekä aikuisopiskeluun osallistuneiden osallistumissyitä ja esteitä.

Opettamiseen oppiminen sidotaan didaktisten periaatteiden ja niiden psykologisten perustelujen avulla.

\section{Aikuisuus ja oppiminen}

Kun tarkastellaan aikuisen oppimista, tulee ensimmäisenä mieleen aikuisuuden merkitys oppimiselle. Kirjassa ei tätä juurikaan käsitellä. Niemi tuo esille, että aikuisella on hyvät oppimisedellytykset, että hän valikoi opittavia tietoja ja että hänen työmuistinsa on voimakkaasti kuormittunut. Vauras ja Kinnunen painottavat ymmärtävän oppimisen merkitystä aikuisuudessa; opetustilanteessa aikuisuuden tunnusmerkkejä ovat tavoitteisuus ja elämänkokemus sekä esimerkiksi ideologiset ristiriidat, kilpailu asiantuntemuksesta tai rakastuminen.

Aikuisen elämäntilanne oli jätetty Hypénin harteille, joka kuittaa sen viittaamalla ihmisten tapoihin käsitellä elämäntoiminnoissa ilmeneviä ristiriitoja, elämänstrategioihin. Onko aikuinen luopuva, välttävä, sopeutuva, jäykästi ekspensiivinen vaiko luovan ekspensiivinen. Näitä tyyppejä ei liitetä mitenkään koulutusinstituution ulkopuolisiin elämäntilanteisiin, opetustilanteisiin kyllä. Osallistumis- 
syiden ja -esteiden luetteleminen ei myöskään riitä antamaan kehityksellistä kuvaa oppimisprosesseista.

Aikuisen oppimisessa merkityksellistä on kuitenkin erityisesti aikuisen elämäntilanne, sen kehityshistoria ja siinä piilevät kehitykselliset ristiriidat. On tärkeää huomata, että skeemat saavat aina sisältönsä yksilön kontakteista ympäristöönsä. Vastaavasti tiettyjen skeemojen aktivoituminen on sidoksissa aikuisen elämänrakenteen keskeisiin kehitystehtäviin. Aikuispsykologinen kirjallisuus on voimakkaasti painottanut elämäntilanteen merkitystä oppimistapahtuman ennakkojäsentäjänä (esim. Bischof 1976, Gould 1978, Knox 1981, Levinson et ass. 1978). Elämänrakenteen ja kognitiivisen rakenteen yhteyteen on myös viime aikoina kiinnitetty enenevää huomiota (esim. Marton \& Wenestam 1984, Schön 1983).

Teoksessa on oppimistapahtuma voimakkaasti sidottu opetustapahtumaan, institutionaaliseen kontekstiin. Todellisuudessa aikuisen oppiminen on paljon voimakkaammin osa jokapäiväistä elämää. Esimerkiksi Allen Tough $(1979,1982)$ on tutkimuksissaan todennut, että aikuisten oppimisprojekteista suurin osa ei sijoitu instituutioiden puitteisiin. Näin ollen olisi ehkä ollut paikallaan myös tarkastella enemmän oppimista opetustapahtuman ulkopuolella.

Kognitiivisessa psykologiassa aineksia uuteen aikuisen oppimisen paradigmaan olen näkevinäni eniten maailmankuvan käsitteessä yksilön sisäisen todellisuuden ilmentäjänä. Itse asiassa aikuiskasvatukseen liittyen Saksan liittotasavalta ollaan rakentamassa elämänkentan ja arkikokemuksen käsitteisiin nojaavaa teoriaperustaa (esim. Siebert 1985). Maailmankuva ja elämänkenttä ovat käsittääkseni jonkinlaisessa sukulaisuussuhteessa keskenään.

\section{Mitä on oppiminen?}

Pekka Niemi määrittelee oppimisen teoksen johdannossa "meissä itsessämme tapahtuvaksi toiminnaksi, joka muuttaa ja rikastuttaa käsityksiämme maailmasta",. Oppiminen nähdäänkin pitkälle kognitiivisena, yksilön sisäisten mallien ja skeemojen ohjaamana tietojen mieleenpainamisena ja niiden ottamisena jälleen käyttöön.

Vaikka esitetty oppimisnäkemys onkin perusteltu ja tutkimustuloksiin perustuva, se ei kuitenkaan ole ainoa mahdollinen. Esimerkiksi Edwin L. Simpson (1980) erittelee aikuisen oppimisen tarkastelussa käytettyjä näkökulmia ja havaitsee niiden olevan varsin erilaisessa suhteessa erilaisiin oppimisteorioihin. Esimerkiksi behaviorismin, humanistisen psykologian ja aikuiskasvatuksen kriittisen teorian (esim. Mezirow 1981) omaksumat oppimisnäkemykset eroavat teoksessa esitetyistä. Lisäksi kognitiivisen oppimisteorian sisällä on myös variaatioita, joita olisi mielellään suonut pohdittavan. Kaikki eri oppimisteoriat ja niiden variaatiot aina sijoittuvat johonkin historialliseen kontekstiin, ne ovat peräisin jostain ja ne ovat johonkin siirtymässä. Historiallinen konteksti olisi antanut lukijalle paremmat mahdollisuudet itse analysoida esitettyä oppimisnäkemystä. Aikuiskasvatuksen approbaturiin liittyen ainoastaan yhden oppimisen teorian selvittäminen opiskelijoille antaa varsin suppean kuvan muuten niin laajasta teoriakentästä.

Kirjassa esitetty oppimisnäkemys on psykologinen, vaikka sitä yritetäänkin sitoa opetustilanteisiin. Tilanteet tulevat erilaisissa oppimisnäkemyksissä paljonkin voimakkaammin esille, ja olisikin toivonut, että erityisesti aikuiskasvatukseen liittyvät organisatoriset ja yhteisölliset kontekstit olisi huomioitu. Puhu- taanhan sentään organisaation oppimisesta (esim. Argyris \& Schön 1978) ja yhteisön oppimisesta (esim. Wright 1980). Kognitiivisen rakenteen ja elämänrakenteen välinen yhteys on oppimisen kannalta tarkasteltuna varsin tärkeä.

\section{Oppimisen arvoperusta}

Kognitiivinen teoria oppimisesta korostaa voimakkaasti oppijan omaehtoisen säätelyn merkitystä. Opittaessa yksilö itse valikoi ja tulkitsee ympäristöstä saatavaa informaatiota ja tekee itse päätöksensä toimintaan ryhtymisestä. Näin tarkasteltuna kognitiivinen teoria tukee voimakkaasti usein aikuiskasvatuksen taustalla olevaa humanistista ihmiskuvaa.

Tilanteen ei kuitenkaan tarvitse olla tällainen, kuten teoksen kirjoittajat osoittavat. Yksilön minäkuva ja maailmankuva nähdään opettajan säätelemisen kohteina, oppimistavoitteiden määrääminen alistetaan opettajalle ja viestinnässä painotetaan sitä, miten opiskelijat saataisiin tehokkaimmin omaksumaan tietty oppiaines. Pekka Niemi tarjoaa hyvän esimerkin:

"...opettajan parhaita tavoitteita on tarjota oppilaalle eheä ja hyvin jäsentynyt maailmankuva, joka auttaa ymmärtämään maailmaa ja esittäytyy opettajalle sekä palkkiona että piiskana. Tällaisessa tilanteessa tarvitaan hyvää liittolaista. Tämän opettaja saa oppilaan maailmankuvan yhdestä osasta, hänen minäkuvastaan. ... (minäkuva) on ainakin yksi tie, jota pitkin vaikeatkin asiat näyttävät uppoavan sangen helposti sisään." (s. 23, 24).

Behaviorismiin sisältyneet arvolähtökohdat näyttävät saaneen hienostuneemman tulkintansa. Sellaisena se lienee myös vaarallisempi. Erityisesti koska nyt valjastetaan 
yksilön minuus opettajan vallan alle; behaviorismissa valjastettiin ainoastaan yksilön reaktiot.

Oppimisen arvoperusta jää kirjassa pitkälle pohtimatta, vaikka omien arvojen evaluointi kuuluukin metakognition piiriin. Jos tarkasteluun olisi sisällytetty muiden oppimisteorioiden esittämiä näkemyksiä, arvot olisivat varmasti nousseet selvemmin esiin. Nyt opiskelijalle tarjotaan eheä ja hyvin jäsentynyt maailmankuva, muttei huomioida, että se pitää sisällään paljon kritiikin aihioita, jotka saattavat osoittaa, ettei se olekaan niin ehyt ja jäsentynyt kuin ensin luultiin.

\section{Lopuksi}

Yleisesti ottaen teos ei ole niin negatiivinen kokemus kuin edellisestä voisi päätellä. Itse asiassa luvut tietojen ja taitojen oppimisesta ovat oikein onnistuneita, jos unohdetaan niiden keskittyminen ainoastaan yhden näkökulman esittämiseen. Ne ovat hyvin ja selkeästi kirjoitettuja sekä havainnollistavat onnistuneesti oppimisen luonnetta. Luku 'Aikuinen ihminen tiedonkäsittelijänä' laiminlyö aikuisuuden käsittelyn, muilta osin se toimii hyvänä johdattelevana jaksona teokseen. Muut luvut ovat enemmän tai vähemmän täyteaineistoa; tekijät eivät tainneet liikkua omimmalla alueellaan.

Aikuiskasvatuksen approbaturin oppikirjana teokselta voitaisiin kuitenkin vaatia monipuolisempaa otetta oppimiseen. Aikuisuuden olennaisena osana yksilön elämäntilanne olisi pitänyt ottaa paremmin huomioon; oppimisen kehityspsykologinen puoli jää myös hyvin vähälle tarkastelulle. Muiden oppimisteorioiden ja -näkemysten tarkastelu olisi myös rikastuttanut kirjan antia. Samalla olisi tullut ehkä pohdituksi sitä arvoperustaa, jolle kirja rakentuu. Tällaisenaan kirja jättää muille tämän opintojakson kirjoille kovin suuren aukon paikattavaksi.

Jos tarkastellaan teosta omana kokonaisuutenaan, irrallaan aikuiskasvatuksen approbaturista, arvio on huomattavasti myönteisempi. Aikuiskasvatuksen kentällä tarvitaan uusia koherentteja oppimisnäkemyksiä, jotka on esitetty selkeästi ja ymmärrettävästi. Oppiminen on jäänyt liian usein liian vähälle huomiolle aikuiskasvatuksen piirissä.

\section{Antti Kauppi}

\section{Lähteet}

Argyris, C. \& Schön, D.A. 1978. Organizational Learning: A Theory of Action Perspective. Reading, Mass.: Addison-Wesley.

Bischof, L.J. 1976. Adult Psychology. Second Edition. New York: Harper \& Row.

Gould, R. 1978. Transformations: Growth and Change in Adult Life. New York: Simon \& Schuster.

Knox, A.B. 1981. Adult Development and Learning. San Francisco: Jossey Bass.

Levinson, D.J. \& ass. 1978. Seasons of a Man's Life. New York: Ballantine Books.

Marton, F. \& Wenestam. C-G. (red.) 1984. Att uppfatta sin omvärld. Varför vi förstår verkligheten på olika sätt. Stockholm: AWE/Gebers.

Mezirow, J. 1981. A Critical Theory of Adult Learning and Education. Adult Education, $32,1,3-24$.

Schön, D.A. 1983. The Reflective Practitioner. How Professionals Think in Action. New York: Basic Books.

Siebert, H. 1985. Paradigmen der Erwachsenenbildung. Zeitschrift fur Pädagogik, 31, 5, 577596.

Simpson, E.L. 1980. Adult Learning Theory: A State of the Art. In Adult Development and Learning. Washington D.C.: U.S. Department of Education/Office of Educational Research/National Institute of Education.

Tough, A. 1979. The Adult's Learning Projects. Second Edi- tion. Research in Education Series No. 1. The Ontario Institute of Education.

Tough, A. 1982. Intentional Changes. Chicago: Follett.

Wright, J. 1980. Community Learning: A Frontier for Adult Education. In Boyd, R.D. \& Apps, J.W. (ed.) Redefining the Discipline of Adult Education. San Francisco: Jossey Bass. 